\title{
Influence of worker age on the infestation of resistant and susceptible honey bees (Apis mellifera) with tracheal mites (Acarapis woodi)*
}

\author{
José D. VILLA \\ USDA, ARS Honey Bee Breeding, Genetics and Physiology Laboratory, 1157 Ben Hur Road, Baton Rouge, \\ LA 70820, USA
}

Received 23 February 2007 - Revised 13 September 2007 - Accepted 21 September 2007

\begin{abstract}
In an earlier study, resistant and susceptible workers exposed to tracheal mites one, two, three or four days post-emergence showed a decline in infestation. I further investigated the combined effects of worker age and of strain on infestation with tracheal mites. In four separate tests, workers were aged to evenly distributed classes reaching maximum ages of 9,24, 48 and $96 \mathrm{~h}$. The following factors influenced infestation levels: (1) overall, infestation of workers from resistant colonies was significantly lower than for susceptible colonies (2) age produced parallel rates of decline in infestation in both resistant and susceptible workers in the first three tests and (3) in the test up to $96 \mathrm{~h}$, the large infestation differences in the youngest workers became very similar in workers aged three or four days. The differences between strains were highest at the youngest ages in all tests, indicating that evaluations of potentially resistant colonies should use the youngest workers possible
\end{abstract}

Acarapis woodi / Apis mellifera / genetic resistance / selection / susceptibility

\section{INTRODUCTION}

The use of honey bees (Apis mellifera L.) with genetic resistance to tracheal mites (Acarapis woodi (Rennie)) eliminates the cost of monitoring or controlling this parasite. Field tests with strains from Britain (Danka et al., 1995), Yugoslavia (Guzman et al., 1998) and the Russian Far East (Guzman et al., 2001, 2005) have shown that most of these colonies maintain tracheal mites below damaging levels, while colonies from unselected North American stocks tend to develop critical infestations. Early attempts at artificial selection showed that the level of tracheal mite resistance in such unselected bees could be rapidly improved (Page and Gary, 1990). The benefits of this approach at a larger scale were

Corresponding author: J.D. Villa, jvilla@ars.usda.gov

* Manuscript editor: Klaus Hartfelder demonstrated by greatly improving the tracheal mite resistance of a breeding population in Ontario (Nasr et al., 2001). Despite the evidence for the value of genetic resistance, commercially available strains in the United States are still highly variable in their susceptibility (Danka and Villa, 2000, unpubl. data).

A bioassay or screening test is a useful tool in assessing colony phenotypes and provides information which correlates well with infestation of field colonies (Lin et al., 1996; Nasr et al., 2001). A bioassay measures differences in the infestation of young workers (typically less than $24 \mathrm{~h}$ from emergence) from a number of source colonies when simultaneously exposed in a highly infested colony (Gary and Page, 1987). This approach can greatly reduce the time and effort required to evaluate colonies and eliminates some of the sources of variability encountered in field tests. Additionally, this technique has been used to 
investigate possible mechanisms of resistance (Danka and Villa, 1996, 1998, 1999; Villa, 2006; McMullan and Brown, 2006a, b), and to evaluate whether resistance of workers is also expressed in queens and drones (Dawicke et al., 1992; Villa and Danka, 2005).

Aside from differences between young workers of different genetic origins, there are clear age differences in the potential of workers to become infested with tracheal mites. Older bees are much less likely to be infested by migrating foundress female mites than newly emerged workers (Morgenthaler, 1930; Lee, 1963). In a group of workers from the same source, aged from one to ten days, infestation declined sharply in the younger bees to almost no infestation in the oldest workers when exposed simultaneously to infestation (Gary et al., 1989). A similar decline in infestation of one, two, three and four day-old workers was seen in both susceptible and resistant strains (Villa, 2006).

The experiments described here explored differences in infestation between strains in age classes narrower than the $24 \mathrm{~h}$ previously reported (Gary et al., 1989; Villa, 2006). These experiments were conducted to explore whether knowledge of worker age can improve the resolution of bioassays for resistance and to further the understanding of mechanisms of resistance. The following questions were addressed: (1) Does the infestation potential decrease with age at similar rates in workers from highly resistant and susceptible colonies?, (2) Is there an optimal age at which absolute differences between colonies with contrasting levels of resistance is the largest?, (3) Are there any practical recommendations concerning worker age which can be used in bioassays or short tests for genetic resistance?

\section{MATERIALS AND METHODS}

\subsection{Genetic origin of workers}

Test worker bees came from colonies with contrasting levels of susceptibility ( $>$ two-fold differences in infestation in bioassays) or were obtained from colonies propagated from previously screened parents. Propagated colonies had selected queens which were instrumentally inseminated with multiple drones also from selected colonies. Resistant colonies were derived from Russian queen lines 01C-893-Yellow/Yellow and 04A136-White/Green (Rinderer et al., 2005). Susceptible colonies were obtained from commercially available sources in the United States.

\subsection{Aging and inoculation of workers}

The four tests used resistant and susceptible workers separated into evenly distributed age classes; the youngest workers were newly emerged, while the oldest were of a maximum age according to the test. Test 1 was designed to measure variation at the earliest possible ages, with three age classes, a maximum age of $9 \mathrm{~h}$, and workers obtained from one resistant colony and one susceptible colony. Tests 2, 3 and 4 used workers from two resistant and two susceptible colonies which were divided into four age cohorts with maximum ages of 24, 48 and $96 \mathrm{~h}$, respectively. These three tests were designed to investigate the possible convergence in infestation between strains at the older ages. For each test, brood combs with emerging workers from test colonies were brushed free of adult bees and placed in individual cages in incubators. After the appropriate emergence time for a colony within an age class within each test, ca. 30-50 workers were marked with enamel paint dots on the abdomen indicating colony and age class. They were kept according to colony source and age in hoarding cages with honey and water provided ad libitum. All the bees for each test were simultaneously introduced into a separate colony for exposure in the same conditions to tracheal mite infestation. Introductions were made into colonies with high infestations ( $>70 \%$ of workers infested) in the spring or autumn to guarantee high transfer rates of mites. Marked workers were retrieved from the respective inoculation colony after five to six days and frozen. Bees were dissected by removing the prothoracic collar and separating the infested tracheae to count the number of foundress female mites. Due to variation in rates of emergence, in acceptance and retrieval from inoculation colonies, between 13 and 50 workers contributed data to each colony by age class combination; 20 or more bees were dissected in 49 out of 54 of the colony by age combinations involved in the four tests. 
Table I. Results of analyses of variance on the infestation of worker bees with female tracheal mites. Strain indicates the effect of worker origin as either from resistant or susceptible colonies. Age indicates the numerical effect of worker age. Workers ( $n=$ total dissected for each test) were aged to equally divided age classes up to the maximum age indicated. Linear regression of $\log _{e}$ (mites per bee +0.1 ) on the midpoint of each age class provided the best fit to the data. Random components of variance for each test are indicated separately.

\begin{tabular}{|c|c|c|c|c|c|c|}
\hline Test & Max. Age & Fixed Effect & $d f$ & \multicolumn{2}{|l|}{$F$} & $P>F$ \\
\hline \multirow[t]{3}{*}{1} & 9 hours & Strain & 1,175 & \multicolumn{2}{|l|}{9.26} & 0.0027 \\
\hline & $n=179$ & Age & 1,175 & \multicolumn{2}{|l|}{8.09} & 0.0050 \\
\hline & & Strain $\times$ Age & 1,175 & \multicolumn{2}{|l|}{0.04} & 0.8514 \\
\hline \multirow[t]{3}{*}{2} & 24 hours & Strain & 1,3 & \multicolumn{2}{|l|}{11.86} & 0.0343 \\
\hline & $n=458$ & Age & 1,452 & \multicolumn{2}{|l|}{48.66} & $<0.0001$ \\
\hline & & Strain $\times$ Age & 1,452 & \multicolumn{2}{|l|}{0.93} & 0.3355 \\
\hline \multirow[t]{3}{*}{3} & 48 hours & Strain & 1,13 & \multicolumn{2}{|l|}{33.46} & 0.0001 \\
\hline & $n=496$ & Age & 1,13 & \multicolumn{2}{|l|}{20.41} & 0.0006 \\
\hline & & Strain $\times$ Age & 1,13 & \multicolumn{2}{|l|}{1.63} & 0.2248 \\
\hline \multirow[t]{5}{*}{4} & 96 hours & Strain & 1,20 & \multicolumn{2}{|l|}{31.74} & $<0.0001$ \\
\hline & $n=582$ & Age & 1,577 & \multicolumn{2}{|l|}{35.75} & 0.0001 \\
\hline & & Strain $\times$ Age & 1,577 & \multicolumn{2}{|l|}{9.15} & 0.0026 \\
\hline & \multicolumn{6}{|c|}{ Components of Variance for Random Effects: } \\
\hline & \multicolumn{2}{|c|}{ Colony within Strain } & \multicolumn{3}{|c|}{ Colony $\times$ Age within Strain Residual } & \\
\hline 1 & & 0.0000 & 0.0000 & & 1.6114 & \\
\hline 2 & & 0.1312 & 0.0000 & & 1.9238 & \\
\hline 3 & & 0.0000 & 0.0258 & & 1.4987 & \\
\hline 4 & & 0.0043 & 0.0000 & & 1.2430 & \\
\hline
\end{tabular}

\subsection{Statistical analyses}

Each test consisted of a split plot design with the two strains as the main unit (with colonies as replicates for strain) and with age as the subunit (with bees as replicates for age). Analysis of variance (Proc Mixed, SAS Institute, 2000) was used to measure the fixed effects of strain, of the midpoint of the age classes as a numerical variable, and of strain $\times$ age. The random effects included colony within strain, colony $\times$ age within strain, and a residual error (bee to bee variability). Transformation to $\log _{e}$ (foundress mites in each bee +0.1 ) homogenized variances at the different ages and also permitted to model the effects of age as a log-linear trend. The linear relationship of age to the logarithm of infestation can thus be represented in the form of the equation $\mathrm{y}=a b^{\mathrm{x}}$ (with $\mathrm{a}=\mathrm{y}$-intercept of the equation, $\mathrm{b}=$ slope, and $\mathrm{x}=$ age in hours). This permitted comparisons in each test between strains of the slopes and intercepts of the exponential decline in infestation.

\section{RESULTS}

Age and genetic strain strongly influenced the infestation of workers exposed to tracheal mites in the common environment of heavily infested colonies in each of the four tests (Tab. 1). In all four tests, susceptible bees had higher mite infestations than resistant bees at any age, but differences became smaller at three and four days (Fig. 1). While relative differences between resistant and susceptible bees were clear in each test, the infestations in each test varied. Under local conditions, time in the spring and autumn can influence the 

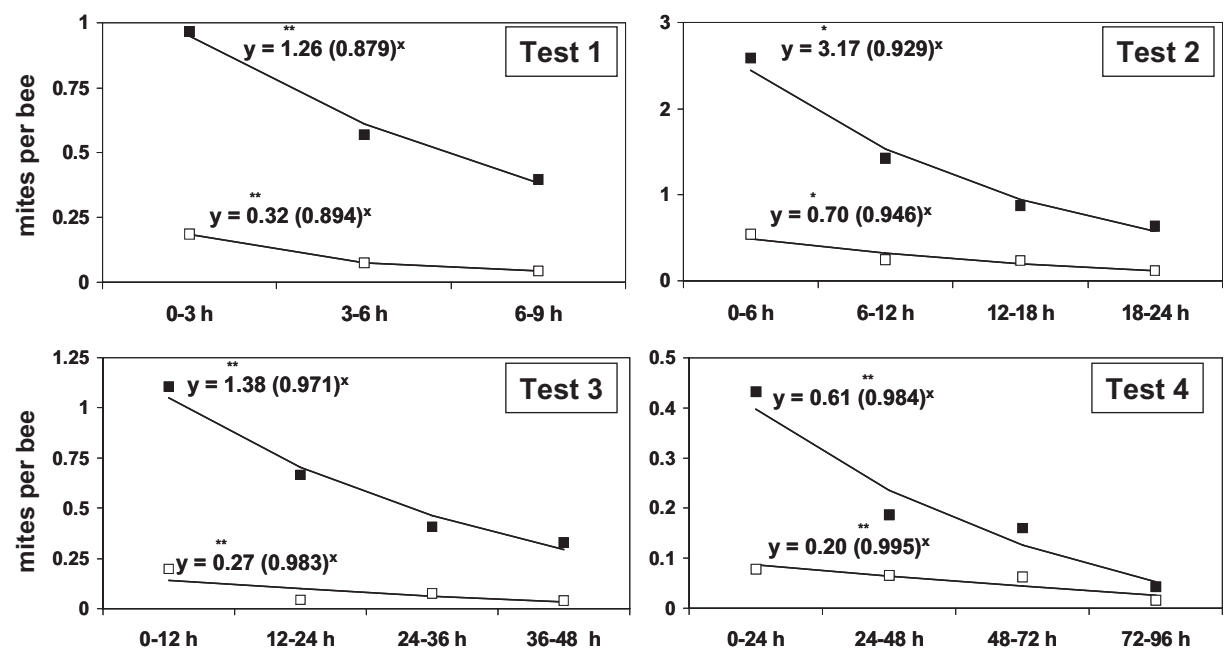

Figure 1. Number of female tracheal mites per bee (least squares means) in susceptible (घ) and resistant (ם) workers of different ages (centered around the midpoint of the age classes). Data were transformed to $\log e_{e}+0.1$. Lines and equations show the best fit log-linear model $\left(y=a b^{x}\right)$ between the two variables derived from the analysis of variance. In tests 1, 2 and 3 there were no significant differences between strains in $\mathrm{b}$, slope of the log-linear relationship, but there were significant differences in a (the $y$-intercept, $* 0.01<P<0.05$, ** $P<0.01$ above the respective pairs of values). In Test 4 , slopes differed significantly between strains $(* * P<0.01)$.

dynamics of mite transfer even in highly infested colonies.

The rate of decline in infestation was similar between the two strains in the three tests with bee ages up to $48 \mathrm{~h}$ at first exposure to mites. In test 1 (bees $<9 \mathrm{~h}$ post emergence), the $95 \%$ confidence intervals for the slopes relating infestation to age were $0.777-1.030$ and $0.805-0.960$ for resistant and susceptible bees, respectively (see Fig. 1). For test 2 (bees aged up to $24 \mathrm{~h}$ ), the corresponding values were $0.922-0.967$ and $0.905-0.954$. For test 3 , the corresponding confidence limits for bees aged up to $48 \mathrm{~h}$ were $0.968-0.999$ and 0.9560 0.986 . In the test with bees up to 96 hours old (Test 4), there was a significant interaction of strain and age (Tab. 1), indicating differing rates of decline in infestation between the strains; the corresponding confidence limits for resistant and susceptible bees did not overlap (0.978-0.989 vs. 0.990-1.00). This interaction in Test 4 is evident in the initial difference of infestation in the youngest workers $(<24 \mathrm{~h})$, merging into a more similar infestation at ages 72-96 h (Fig. 1).

\section{DISCUSSION}

These experiments confirmed that differences between colonies in potential infestation by tracheal mites typically used in bioassays (workers emerged during $24 \mathrm{~h}$ ) can be found at any age of exposure up to about $48 \mathrm{~h}$. However, absolute differences between strains are highest in the youngest bees and lowest in the oldest bees, particularly those three or four days old. A similar pattern was evident in earlier experiments with workers of similar origins aged to $24 \mathrm{~h}$ classes up to 4 days (Villa, 2006).

The youngest ages of workers maximize the expression of colony differences in infestation potential. The optimal timing for a bioassay would be to use teneral bees (e.g. $<3 \mathrm{~h}$ post emergence), but there may be practical limitations in obtaining adequate sample sizes if such a narrow band of ages is used. Alternatively, if bees are marked to also indicate age cohort, age can be incorporated as a blocking factor in statistical analyses to improve the resolution of bioassays. The benefits of this approach have to be balanced with 
the time requirements and may be impractical for simultaneously screening large numbers of colonies. The most efficient approach for screening large numbers of colonies is to use the youngest workers possible and to increase the sample sizes by obtaining workers from as many combs as possible.

The relative decline in infestation, measured as the slope of the log-linear equation relating infestation to age, was similar in both susceptible and resistant workers within age classes up to 9, 24 and 48 h (tests 1, 2 and 3, respectively). Similar parallel declines with age, even in bees prevented from autogrooming due to midleg-gluing (Villa, 2006), suggest that there are common age-related factors independent of autogrooming ability (likely a change in cuticular chemistry as bees age; G.W. Otis, unpubl. data) that explain a decline in potential for mite infestation. Thus, the potential for infestation of an individual worker is governed by the interaction of age-dependent factors different from the genetically determined ability to use midlegs to autogroom. Resistant bees do not simply have a narrower window of high vulnerability to infestation. At any age, they reduce infestation via autogrooming below a gradually declining level determined by other factors.

\section{ACKNOWLEDGEMENTS}

I thank Debbie Boykin for assistance with statistical analyses and Victor Rainey for help with field work and dissections. Robert Danka, Gard Otis, Diana Sammataro, Thomas Rinderer and an anonymous reviewer provided useful suggestions on the manuscript. This research was conducted in cooperation with the Louisiana Agricultural Experiment Station.

Influence de l'âge des ouvrières sur l'infestation par l'acarien des trachées (Acarapis woodi) d'abeilles (Apis mellifera) sensibles et résistantes.

Acarapis woodi / Apis mellifera / résistance génétique / sélection / sensibilité résistance / parasite

Zusammenfassung - Einfluss des Alters auf den Befall mit Tracheenmilben (Acarapis woodi) bei resistenten und befallsanfälligen Honigbienen (Apis mellifera). In der vorliegenden Arbeit untersuchte ich die Kombination der Effekte von Arbeiterinnenalter und genetischer Abstammung (resistente gegen anfällige Völker) auf den potentiellen Befall junger Arbeiterinnen mit Tracheenmilben. In getrennter Form sind die Effekte dieser Faktoren bereits bekannt (z.B. Gary et al., 1989; Danka und Villa, 1996). Vor kurzem untersuchte ich ebenfalls die Effekte von genetischer Abstammung und Eigenputzverhalten bei Arbeiterinnen 1, 2, 3 und 4 Tage nach dem Schlüpfen und fand dabei signifikante Effekte in den Variablen Abstammung, Behinderung im Putzverhalten und Alter (Villa, 2006). Die vorliegende Arbeit beleuchtet jetzt genauer die Details der Milbenbefallsmuster bei jüngeren Arbeiterinnen und in einem engeren Zeitfenster.

Die in den Versuchen eingesetzten Arbeiterinnen kamen aus Völkern, die sich entweder in vorhergehenden Biotests als stark unterschiedlich in Hinsicht auf Befallsanfälligkeit erwiesen hatten, oder sie stammten aus Völkern, die aus früher getesteten Eltervölkern hervorgegangen waren. Die vier Tests wurden mit resistenten und anfälligen Arbeiterinnen getrennt nach Altersklassen durchgeführt, wobei die jüngsten Arbeiterinnen frischgeschlüpft waren und die ältesten das Höchstalter des jeweiligen Tests erreicht hatten. Die erste Testreihe mit drei Altersklassen und einem Höchstalter von $9 \mathrm{~h}$ war angelegt, um Variation im frühstmöglichen Alter aufzudecken. In den Testreihen 2, 3 und 4 wurden vier Altersklassen mit Höchstaltern von 24, 48 und 96 h untersucht.

Alter und genetische Abstammung zeigten in allen vier Testreihen einen starken Einfluss auf den Befall der Arbeiterinnen (Tab. I). Anfällige Bienen zeigten bei allen Altersklassen einen höheren Milbenbefall, aber diese Unterschiede schwächten sich mit zunehmendem Alter nach drei bis vier Tagen ab (Abb. 1). Für die Altersklassen bis 48 h nach Milbenerstbefall waren die Abnahme in den Befallraten für die beiden genetischen Abstammungen ähnlich. Bei bis zu $96 \mathrm{~h}$ alten Bienen (Test 4) zeigte sich dann eine starke Interaktion zwischen $\mathrm{Ab}$ stammung und Alter. Die höchste Befallsanfälligkeit und die grössten Unterschiede zwischen resistenten und anfälligen Arbeiterinnen beobachteten wir bei frischgeschlüpften Bienen, und beide $\mathrm{Pa}$ rameter nahmen mit zunehmendem Alter ab. Bei der Begutachtung potentiell resistenter Völker sollten deshalb jeweils die jüngstmöglichen Arbeiterinnen getestet werden. Der Ähnlichkeit, die die beiden genetischen Abstammungen hinsichtlich ihres altersabhängigen Abfalls in der Befallswahrscheinlichkeit zeigten, könnten gemeinsame Faktoren, wie z.B. eine Abnahme in der Attraktivität für Milben, zugrundeliegen.

Acarapis woodi / Apis mellifera / genetische Resistenz / Selektion / Befallsanfälligkeit 


\section{REFERENCES}

Danka R.G., Villa J.D. (1996) Influence of resistant honey bee hosts on the life history of the parasite Acarapis woodi, Exp. Appl. Acarol. 20, 313-322.

Danka R.G., Villa J.D. (1998) Evidence of autogrooming as a mechanism of honey bee resistance to tracheal mite infestation, J. Apic. Res. 37, 39-46.

Danka R.G., Villa J.D. (1999) Paravestibular hairs of British Buckfast honey bees do not regulate genetic resistance to Acarapis woodi, J. Apic. Res. $38,221-223$.

Danka R.G., Villa J.D. (2000) A survey of tracheal mite resistance levels in U.S. commercial queen breeder colonies, Am. Bee J. 140, 405-407.

Danka R.G., Villa J.D., Rinderer T.E., Delatte G.T. (1995) Field test of resistance to Acarapis woodi (Acari: Tarsonemidae) infestation and of colony production by four stocks of honey bees (Hymenoptera: Apidae), J. Econ. Entomol. 88, 584-591.

Dawicke B.L., Otis G.W., Scott-Dupree C., Nasr M. (1992) Host preference of the honey bee tracheal mite (Acarapis woodi (Rennie)), Exp. Appl. Acarol. 15, 83-98.

Gary N.E., Page R.E. Jr. (1987) Phenotypic variation in susceptibility of honeybees, Apis mellifera, to infestation by tracheal mites, Acarapis woodi, Exp. Appl. Acarol. 3, 291-305.

Gary N.E., Page R.E. Jr., Lorenzen K. (1989) Effect of age of worker honey bees (Apis mellifera) on tracheal mite (Acarapis woodi) infestation, Exp. Appl. Acarol. 7, 153-160.

Guzman L.I. de, Rinderer T.E., Delatte G.T. (1998) Comparative resistance of four honey bee (Hymenoptera: Apidae) stocks to infestation by Acarapis woodi (Rennie) (Acari: Tarsonemidae), J. Econ. Entomol. 91, 1078-1083.

Guzman L.I. de, Rinderer T.E., Delatte G.T., Stelzer J.A., Beaman L., Harper C. (2001) An evaluation of Far-eastern Russian honey bees and other methods for the control of tracheal mites, Am. Bee J. $141,737-741$.

Guzman L.I. de, Rinderer T.E., Bigalk M., Tubbs H., Bernard S.J. (2005) Russian honey bee (Hymenoptera: Apidae) colonies: Acarapis woodi
(Acari: Tarsonemidae) infestations and overwintering survival, J. Econ. Entomol. 98, 1796-1801.

Lee D.C. (1963) The susceptibility of honey bees of different ages to infestation by Acarapis woodi (Rennie), J. Insect Pathol. 5, 11-15.

Lin H., Otis G.W., Scott-Dupree C.D. (1996) Comparative resistance in Buckfast and Canadian stocks of honey bees (Apis mellifera L.) to infestation by honey bee tracheal mites (Acarapis woodi), Exp. Appl. Acarol. 20, 87-101.

McMullan J.B., Brown M.J.F. (2006a) Brood-cell size does not influence the susceptibility of honey bees (Apis mellifera) to infestation by tracheal mites (Acarapis woodi), Exp. Appl. Acarol. 39, 273 280.

McMullan J.B., Brown M.J.F. (2006b) The role of autogrooming in the differential susceptibility to tracheal mite (Acarapis woodi) infestation of honeybees (Apis mellifera) held at both normal and reduced temperatures during pupation, Apidologie $37,471-479$.

Morgenthaler O. (1930) New investigations on acarine disease, Bee World 11, 49-50.

Nasr M.E., Otis G.W., Scott-Dupree C. (2001) Resistance to Acarapis woodi by honey bees (Hymenoptera: Apidae) - Divergent selection and evaluation of selection progress, J. Econ. Entomol. 94, 332-338.

Page R.E. Jr., Gary N.E. (1990) Genotypic variation in susceptibility of honey bees (Apis mellifera) to infestation by tracheal mites (Acarapis woodi), Exp. Appl. Acarol. 8, 275-283.

Rinderer T.E., Guzman L. de, Danka R. (2005) A new phase begins for the USDA-ARS Russian honey bee breeding program, Am. Bee J. 145, 579-581.

SAS INSTITUTE (2000) Online Doc, version 8, SAS Institute Inc., Cary, NC, USA.

Villa J.D. (2006) Autogrooming and bee age influence the migration of tracheal mites to Russian and susceptible worker honey bees (Apis mellifera $\mathrm{L}$ ), J. Apic. Res. 45, 28-31.

Villa J.D., Danka R.G. (2005) Caste, sex and strain of honey bees (Apis mellifera) affect infestation with tracheal mites (Acarapis woodi), Exp. Appl. Acarol. 37, 157-164. 